\title{
Portable EDXRF and principal component analysis for inorganic element determination and provenance of eye shadows
}

\section{EDXRF portátil e análise de componentes principais para a determinação de elementos inorgânicos e proveniência de sombras para os olhos}

\author{
Rafael Molari ${ }^{1}$; Lucas Yoshimi Endo ${ }^{2}$; Carlos Roberto Appoloni ${ }^{3}$; \\ Fábio Luiz Melquiades ${ }^{4}$; Otávio Portezan Filho ${ }^{5}$; Paulo S. Parreira ${ }^{6}$
}

\begin{abstract}
Nowadays cosmetic products play an important role in the life of almost all people. Men and women devote much time, resources and efforts to cultivate personal hygiene and the best possible look along their lives. One of the most widely used kind of cosmetics is eye shadow. X-ray fluorescence (XRF) is a well-established technique, known for its ability to identify and quantify inorganic species in a simple, fast and non-destructive way, however, it is not extensively used in cosmetic analysis. In order to show the potentiality of the technique, portable energy-dispersive X-ray fluorescence spectrometry has been employed in the quantification of inorganic elements in 40 Brazilian eye shadows. It was possible to identify and quantify the elements $\mathrm{Cl}$, $\mathrm{K}, \mathrm{Ca}, \mathrm{Ti}, \mathrm{Cr}, \mathrm{Mn}, \mathrm{Fe}, \mathrm{Cu}, \mathrm{Zn}$ and Bi. Using principal component analysis, specific manufacturers could be distinguished. The X-ray fluorescence methodology associated with principal component analysis proved to be a valuable tool for the discrimination and characterization of cosmetics.
\end{abstract}

Keywords: EDXRF. Principal component analysis. Cosmetics.

\section{Resumo}

Nos dias de hoje, produtos cosméticos desempenham um importante papel na vida de quase todas as pessoas. Homens e mulheres dedicam muito tempo, recursos e esforços para cultivar a higiene pessoal e a melhor aparência possível ao longo de suas vidas. Um dos tipos de cosméticos mais utilizados é a sombra para os olhos. A fluorescência de raios X (XRF) é uma técnica bem estabelecida, conhecida por sua capacidade de identificar e quantificar espécies inorgânicas de maneira simples, rápida e não-destrutiva, no entanto, não é amplamente utilizada em análises de produtos cosméticos. A fim de se mostrar a potencialidade da técnica, fluorescência de raios X por dispersão em energia portátil foi empregada na quantificação de elementos inorgânicos em 40 sombras para os olhos brasileiras. Foi possível identificar e quantificar os elementos $\mathrm{Cl}$, $\mathrm{K}, \mathrm{Ca}, \mathrm{Ti}, \mathrm{Cr}, \mathrm{Mn}, \mathrm{Fe}, \mathrm{Cu}, \mathrm{Zn}$ e Bi. Utilizando a análise de componentes principais, foi possível distinguir os diferentes fabricantes. A metodologia de fluorescência de raios $\mathrm{X}$ associada à análise de componentes principais provou ser uma ferramenta valiosa para a discriminação e caracterização de produtos cosméticos.

Palavras-chave: EDXRF. Análise de componentes principais. Cosméticos.

\footnotetext{
${ }^{1}$ Me., Depto. de Física, UEL, Londrina, PR, Brazil; E-mail: rmolari@uel.br

2 Dr., Depto. de Física, UEL, Londrina, PR, Brasil; E-mail: lucasyendo@yahoo.com.br

3 Prof. Dr., Depto. de Física, UEL, Londrina, PR, Brasil; E-mail: appoloni@uel.br

${ }^{4}$ Prof. Dr., Depto. de Física, UEL, Londrina, PR, Brasil; E-mail: fmelquiades@uel.br

${ }^{5}$ Prof. Dr., Depto. de Física, UEL, Londrina, PR, Brasil; E-mail: otavio@uel.br

${ }^{6}$ Prof. Dr., Depto. de Física, UEL, Londrina, PR, Brasil; E-mail: parreira@uel.br
} 


\section{Introduction}

The use of cosmetics predates written history. Makeup products were created thousands of years ago to give people a more attractive look, to protect their bodies and also as medical care (PARISH; CRISSEY, 1988. WESTMORE, 2001). Nowadays, there are various reasons why cosmetic products continues being an important part of almost everyone's life (WESTMORE, 2001). The improvement in quality of life and the increase in longevity of the population make men and women devote more time, resources and efforts to cultivate personal hygiene and the best possible look along their lives.

Although cosmetics for the purpose of beautifying, perfuming, cleansing or rituals have existed since the antiquity, only in the last century a great progress has been made in the diversification of products and in the safety and protection of the consumer. Consumers have become more and more knowledgeable and demanding, and cosmetics have become more sophisticated, innovative and safe (BAREL; PAYE; MAIBACH, 2009).

One of the most widely used kind of cosmetics are eye shadows. They are cosmetics designed to impart color, mainly to the upper eyelid and it is used to make the eyes of the wearer stand out or look more attractive.

The elemental characterization of a cosmetic product may be important for many reasons, including quality assurance in industry of raw materials or final products and supervision by regulatory agencies. In addition, it has direct application in forensic science (MISRA et al., 1992. MURPHY et al., 2012. SHIMAMOTO; TERRA; BUENO, 2013), as in the analysis of cosmetic residues in crime scenes. Elemental characterization may be verified by analytical methods like X-ray fluorescence spectroscopy.

$\mathrm{X}$-ray fluorescence (XRF) is a well-established technique, known for its ability to identify and quantify inorganic species in a simple, fast and non-destructive way, specially using its energy-dispersive variant, energydispersive X-ray fluorescence (EDXRF). In last decades, XRF has been employed in the elemental analysis of cosmetics. Misra et al. (1992) applied energy-dispersive Xray fluorescence spectrometry in the quantitative analysis of nail polishes. Briggs-Kamara (2012) used energydispersive X-ray fluorescence spectrometry to determine the elemental composition of epidermal cosmetic creams. Kulikov, Latham and Adams (2012) employed wavelength-dispersive X-ray fluorescence (WDXRF) spectrometry for multi-elemental analysis of mineral and traditional ingredient cosmetic powders. Murphy et al. (2012) employed a handheld XRF unit to measure the total mercury content of skin-whitening creams. DaSilva, David and Pejović-Milić (2015) applied total reflection $\mathrm{X}$-ray fluorescence (TXRF) spectrometry in quantification of total lead in lipstick specimens. Melquiades et al. (2015) applied a portable EDXRF system for the elemental concentration determination in different kinds of cosmetics. Classification of samples which contain $S$ in nail polish were determined by Melquiades and da Silva (2016) using EDXRF and multivariate analysis. Santos et al. (2018) employed energy dispersive X-ray fluorescence for inorganic elements quantification in eye shadows.

The Principal Component Analysis (PCA) is one of the most important modern methods of treating multivariate data. It is an important data compression tool that make possible original dimensionality reduction while preserving the relevant information. In PCA the original information is transformed into a more compact and summarized set of information than the previous one. These qualities make the PCA a suitable tool for analysis of the multi-elemental data from XRF. Through the graphical representation of the principal components, it is possible to verify the relations between the different variables, to detect and to interpret a pattern among the samples, gathering the similarities and differences among them (WOLD; ESBENSEN; GELADI, 1987).

Considering that EDXRF method is a well-known procedure; has an attractive cost-benefit ratio, allows field application and not requires complex sample preparation, like sample digestion, as in other methodologies, like LIBS (Laser Induced Breakdown Spectroscopy) and ICP-OES (Inductively Coupled Plasma Optical Emission Spectrometry) (GONDAL et al., 2010. BATISTA; DOS SANTOS AUGUSTO; PEREIRAFILHO, 2015. DOS SANTOS AUGUSTO; BATISTA; PEREIRA-FILHO, 2016. MCINTOSH et al., 2016), the main idea of this paper is to show the potentiality of the technique in cosmetic samples analysis. In this way, a portable EDXRF system was employed in the quantification of inorganic elements in eye shadows. Subsequently, the set of EDXRF spectra was analyzed by PCA with the objective to observe similarities among the different manufacturers and suppliers of eye shadows. 


\section{Materials and Methods}

\section{Sample collection and preparation}

In this study, 40 eye shadows acquired from four Brazilian manufacturers and suppliers, representing different colors and shades were analyzed. Each sample has been assigned a code: the letters indicate the manufacturer and the numbers represents the product number in the set of samples from the same manufacturer.

The samples in loose powder form were prepared in triplicate without any kind of chemical preparation. The powder was applied over a thin paper (silk paper), placed on conventional $32 \mathrm{~mm}$ diameter XRF cup (Chemplex Industries Inc.). It was used an appropriate brush in such way that the samples fits in the thin film geometry (VAN GRIEKEN; MARKOWICZ, 2001). Figure 1 shows a sample properly mounted on the XRF cup and Table 1 shows some characteristics of the analyzed samples, i.e., their color, mass applied to the XRF cup and surface density.

Thin-film mono-element standards supplied by Micromatter $^{\mathrm{TM}}$ were also examined for elementary sensitivity determination.

Figure 1 - Eye shadow sample properly mounted on the XRF cup.

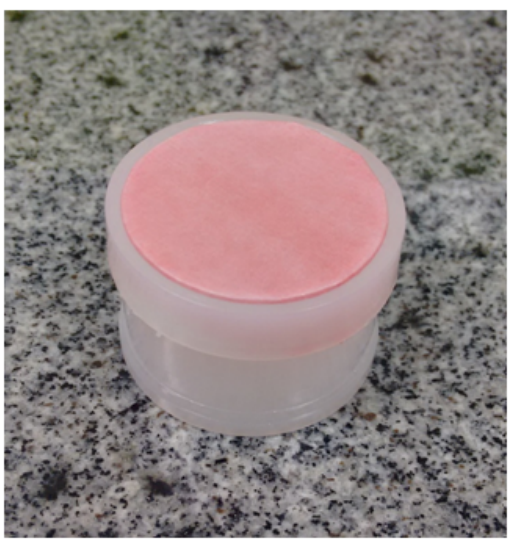

Source: The authors.

\section{Sample analysis}

The data acquisition was carried out with a self-made portable EDXRF system (PARREIRA, 2019), which consists of a mini X-ray tube (Ag target, $4 \mathrm{~W}$, Moxtek Inc., Orem. UT. USA) with a $50 \mu \mathrm{m}$ thick Ag filter and the X-123 complete X-ray spectrometer with Si-PIN detector (FWHM $153 \mathrm{eV}$ for Mn $5.9 \mathrm{keV}$ line, $12.7 \mu \mathrm{m}$ Be window,
Table 1 - Color (informed by the manufacturer), mass applied to the XRF cup and surface density of the samples analyzed.

\begin{tabular}{|c|c|c|c|}
\hline Sample & Color & Mass [g] & $\begin{array}{l}\text { Surface density } \\
{\left[{\left.\mathrm{g} . \mathrm{cm}^{-2}\right]}^{-2}\right.}\end{array}$ \\
\hline $\mathrm{A} 1$ & Pearly green & 0.00098 & 0.000219 \\
\hline A2 & Military green & 0.00100 & 0.000220 \\
\hline A3 & Matte brown & 0.00112 & 0.000227 \\
\hline A4 & Shimmering gold & 0.00106 & 0.000217 \\
\hline B1 & Yellow/gold & 0.00219 & 0.000525 \\
\hline $\mathrm{B} 2$ & Light green & 0.00352 & 0.000820 \\
\hline B3 & Purple & 0.00256 & 0.000602 \\
\hline B4 & White & 0.00292 & 0.000736 \\
\hline B5 & Light brown & 0.00231 & 0.000556 \\
\hline B6 & Bronze & 0.00289 & 0.000768 \\
\hline B7 & Light purple & 0.00330 & 0.000786 \\
\hline B8 & Light pink & 0.00441 & 0.001015 \\
\hline B9 & White & 0.00218 & 0.000476 \\
\hline B10 & Brown & 0.00371 & 0.000797 \\
\hline B11 & Gray & 0.00406 & 0.000822 \\
\hline B12 & White & 0.00387 & 0.001175 \\
\hline B13 & Dark blue & 0.00259 & 0.000544 \\
\hline B14 & Black & 0.00526 & 0.001097 \\
\hline B15 & Ivory & 0.00170 & 0.000379 \\
\hline B16 & Light brown & 0.00231 & 0.000533 \\
\hline B17 & Red earth & 0.00326 & 0.000743 \\
\hline B18 & Brown & 0.00451 & 0.001091 \\
\hline $\mathrm{C} 1$ & Pearly blue & 0.00162 & 0.000412 \\
\hline $\mathrm{C} 2$ & Royal blue & 0.00186 & 0.000440 \\
\hline $\mathrm{C} 3$ & Water green & 0.00168 & 0.000468 \\
\hline $\mathrm{C} 4$ & Bluish green & 0.00172 & 0.000429 \\
\hline $\mathrm{C} 5$ & Peach pink & 0.00218 & 0.000829 \\
\hline C6 & Green & 0.00141 & 0.000437 \\
\hline $\mathrm{C} 7$ & Yellow & 0.00158 & 0.000499 \\
\hline $\mathrm{C} 8$ & Brown & 0.00168 & 0.000395 \\
\hline D1 & Green & 0.00167 & 0.000505 \\
\hline D2 & Orange & 0.00132 & 0.000336 \\
\hline D3 & Sky blue & 0.00110 & 0.000304 \\
\hline D4 & Yellow & 0.00113 & 0.000360 \\
\hline D5 & Pink & 0.00203 & 0.000615 \\
\hline D6 & Light purple & 0.00159 & 0.000509 \\
\hline D7 & Greenish blue & 0.00109 & 0.000323 \\
\hline D8 & Light green & 0.00133 & 0.000491 \\
\hline D9 & Light pink & 0.00225 & 0.000786 \\
\hline D10 & Ivory & 0.00150 & 0.000525 \\
\hline
\end{tabular}

Source: The authors.

Amptek Inc., Bedford, MA, USA) with a $3 \mathrm{~mm}$ diameter Al collimator.

For each sample, twelve measurements were performed. Four measurements for each triplicate, by rotating the sample cup in 90 degree to ensure complete irradiation of the sample area. 
The measurements conditions were: $28 \mathrm{kV}$ and $10 \mu \mathrm{A}$, with acquisition time of $500 \mathrm{~s}$. The spectra were analyzed using the software WinQXAS, from IAEA.

The inorganic elements quantification was performed based on the experimental calibration curve, obtained from the Micromatter ${ }^{\mathrm{TM}}$ standards, and employing the follow equation (1) for thin film samples (VAN GRIEKEN; MARKOWICZ, 2001):

$$
I_{i}=c_{i} \cdot S_{i} \cdot A
$$

where $I_{i}$ is the characteristic X-ray net intensity (cps), $c_{i}$ the concentration $\left(\right.$ g.cm $\left.{ }^{-2}\right), S_{i}$ the elementary sensitivity $\left(\mathrm{cps} . \mathrm{cm}^{2} \cdot \mathrm{g}^{-1}\right)$, determined from the calibration curve, and A the absorption factor. For this methodology, the absorption factor A was set to the unity since the samples were classified as thin film samples (VAN GRIEKEN; MARKOWICZ, 2001). The detection limit (DL) was obtained using Currie's equation (2) (CURRIE, 1968):

$$
D L=\frac{3}{S_{i}} \sqrt{\frac{I_{b g i}}{t}}
$$

where $I_{b g i}$ is the background intensity (cps), and $t$ the measurement time.

The EDXRF results were also processed using MATLAB software (Mathworks Inc., MA, USA). For the PCA analysis a matrix was constructed in such way that the columns refer to the variable (energy) and the lines correspond to each samples.

In order to test the methodology applied in cosmetic analysis, as there is no certified reference material (CRM) available for eye shadows, the same samples were also analyzed by a well-stablished commercial benchtop equipment. The benchtop equipment used is the energy dispersive X-ray spectrometer model EDX-720, from Shimadzu Corp., equipped with a $\mathrm{Rh} \mathrm{X}$-ray tube and a $\mathrm{Si}(\mathrm{Li}) \mathrm{de}$ tector. The measurements conditions were: $15 \mathrm{kV}$ (for the elements from $\mathrm{Na}$ to $\mathrm{Sc}$ ) and $50 \mathrm{kV}$ (for elements from Ti to U), current automatically determined by the measuring system, with acquisition time of $100 \mathrm{~s}$. The quantitative methodology was performed using a routine pre-established by spectrometer software, based on the fundamental parameters equation (VAN GRIEKEN; MARKOWICZ, 2001). For each sample, three measurements were performed. A t-test with $95 \%$ confidence level was applied for the results comparison.

\section{Results and Discussion}

The inorganic elements present in the eye shadow samples and the detection limits for each set of samples are shown in Table 2.

The variations in mass fraction are related to the characteristics of each sample as its coloring and hue, brightness, opacity and skin adhesion capability. The composition of eye shadows is predominantly talc $\left(\mathrm{Mg}_{3} \mathrm{Si}_{4} \mathrm{O}_{10}(\mathrm{OH})_{2}\right)$ with pigments and zinc $\left(\mathrm{Zn}\left(\mathrm{C}_{18} \mathrm{H}_{35} \mathrm{O}_{2}\right)_{2}\right)$ or magnesium $\left(\mathrm{Mg}\left(\mathrm{C}_{18} \mathrm{H}_{35} \mathrm{O}_{2}\right)_{2}\right)$ stearate used as a binder. Kaolin $\left(\mathrm{Al}_{2} \mathrm{Si}_{2} \mathrm{O}_{5}(\mathrm{OH})_{4}\right)$ or calcium carbonate $\left(\mathrm{CaCO}_{3}\right)$ may be added to improve oil absorption and increase the adhesion of the cosmetic on the skin. The pigments play a fundamental role in makeup products because they provide the chromatic modifications necessary for these qualities. Iron oxides, titanium dioxide $\left(\mathrm{TiO}_{2}\right)$, chrome oxide $\left(\mathrm{Cr}_{2} \mathrm{O}_{3}\right)$ and hydrate $\left(\mathrm{Cr}(\mathrm{OH})_{3}\right)$, manganese violet $\left(\mathrm{NH}_{4} \mathrm{MnP}_{2} \mathrm{O}_{7}\right)$, copper powder and iron blue $\left(\mathrm{C}_{18} \mathrm{Fe}_{7} \mathrm{~N}_{18}\right)$ are some of the pigments used in current makeup applications. In addition to diversity in eye shadow color, variation in eye shadow surface characteristics is also available. The surface appearance can vary from matte to a pearled shine. A dull surface texture is produced through the addition of titanium dioxide $\left(\mathrm{TiO}_{2}\right)$, while a pearled shine is obtained using mica $\left(\mathrm{KAl} 2\left(\mathrm{AlSi}_{3}\right) \mathrm{O}_{10}\right)$ or bismuth oxychloride $(\mathrm{BiOCl})$ (DRAELOS, 2001).

The differences in the detection limits, for a given element, can be explained due to the non-homogeneity of the surface density in the analyzed samples. In addition, variations in the chemical composition of the samples produce small changes in the scattering profile of the $\mathrm{X}$-rays (background of the spectrum), contributing to obtain different detection limits among the different sets of samples analyzed.

The inorganic elements present in the eye shadow samples, obtained from measurements with the benchtop system are shown in Table 3.

The quantification of $\mathrm{Cl}$ could not be performed from measurements with the benchtop equipment. The overlapping of the $\mathrm{Cl}$ peaks with the $\mathrm{Rh}$ peaks (from the $\mathrm{X}$ ray tube) made impossible to quantify $\mathrm{Cl}$ in the studied samples.

The results for all detected elements were submitted to a t-test with $95 \%$ confidence level. For K, which was detected in fourteen samples, the results proved be statistically equal only for the samples B11, B13, B15 and B16. 
Table 2 - Results of the elemental analysis of the eye shadows, obtained with the portable system.

\begin{tabular}{|c|c|c|c|c|c|c|c|c|c|}
\hline Sample & $\mathbf{C l}[\mu \mathrm{g} / \mathrm{g}]$ & $\mathbf{K}[\mu \mathbf{g} / \mathbf{g}]$ & $\mathbf{C a}[\mu \mathrm{g} / \mathrm{g}]$ & $\operatorname{Ti}[\mu \mathrm{g} / \mathrm{g}]$ & $\mathrm{Cr}[\mu \mathrm{g} / \mathrm{g}]$ & $\mathbf{F e}[\mu \mathrm{g} / \mathbf{g}]$ & $\mathrm{Cu}[\mu \mathrm{g} / \mathrm{g}]$ & $\operatorname{Zn}[\mu \mathbf{g} / \mathbf{g}]$ & $\mathbf{B i}[\mu \mathrm{g} / \mathbf{g}]$ \\
\hline $\mathrm{A} 1$ & - & - & - & $21,500 \pm 1,500$ & $43,000 \pm 1,100$ & $2,150 \pm 100$ & - & $7,530 \pm 180$ & $21,100 \pm 600$ \\
\hline A2 & $38,000 \pm 9,000$ & - & - & $13,400 \pm 1,200$ & - & $170,000 \pm 14,000$ & - & $7,900 \pm 500$ & $33,800 \pm 1,300$ \\
\hline $\mathrm{A} 3$ & $37,000 \pm 9,000$ & $18,000 \pm 2,000$ & - & $<\mathrm{DL}$ & - & $232,000 \pm 6,000$ & - & $11,500 \pm 600$ & $38,900 \pm 1,700$ \\
\hline A4 & $54,000 \pm 9,000$ & $23,000 \pm 2,000$ & - & $14,900 \pm 1,000$ & - & $147,000 \pm 5,000$ & - & $20,400 \pm 700$ & $60,500 \pm 1,200$ \\
\hline $\begin{array}{l}\text { Detection } \\
\text { Limit }\end{array}$ & 32,500 & 16,400 & & 4,700 & 2,500 & 1,600 & & 800 & 1,600 \\
\hline B1 & - & $21,000 \pm 2,000$ & $<\mathrm{DL}$ & $59,100 \pm 1,500$ & - & $11,290 \pm 190$ & - & $8,700 \pm 190$ & - \\
\hline B2 & - & - & $<$ DL & $82,000 \pm 2,000$ & - & $7,810 \pm 130$ & - & $7,090 \pm 170$ & - \\
\hline B3 & - & $9,500 \pm 1,500$ & $<\mathrm{DL}$ & $111,000 \pm 6,000$ & - & $6,900 \pm 300$ & - & $12,900 \pm 400$ & - \\
\hline B4 & - & $5,700 \pm 700$ & $<\mathrm{DL}$ & $55,000 \pm 1,000$ & - & $2,190 \pm 60$ & - & $9,100 \pm 300$ & - \\
\hline B5 & - & $22,000 \pm 2,000$ & $<\mathrm{DL}$ & $63,300 \pm 1,900$ & - & $29,100 \pm 500$ & - & $12,500 \pm 200$ & - \\
\hline B6 & - & $12,100 \pm 1,300$ & $<\mathrm{DL}$ & $109,000 \pm 4,000$ & - & $497,000 \pm 11,000$ & - & $12,000 \pm 400$ & - \\
\hline B7 & - & $6,400 \pm 800$ & $<$ DL & $67,000 \pm 2,000$ & - & $3,580 \pm 110$ & - & $6,660 \pm 170$ & - \\
\hline B8 & - & - & $<$ DL & $33,600 \pm 1,600$ & - & $1,880 \pm 90$ & - & $9,000 \pm 300$ & - \\
\hline B9 & - & - & $3,200 \pm 1,400$ & $44,000 \pm 3,000$ & - & $2,190 \pm 180$ & - & $17,000 \pm 800$ & - \\
\hline B10 & - & $<\mathrm{DL}$ & $<\mathrm{DL}$ & $1,650 \pm 180$ & - & $215,000 \pm 7,000$ & - & $8,100 \pm 300$ & - \\
\hline B11 & - & $12,800 \pm 1,200$ & $<\mathrm{DL}$ & $50,300 \pm 900$ & - & $16,100 \pm 400$ & - & $8,700 \pm 300$ & - \\
\hline B12 & - & $<\mathrm{DL}$ & $<\mathrm{DL}$ & $35,300 \pm 1,400$ & - & $1,410 \pm 40$ & - & $5,800 \pm 400$ & - \\
\hline B13 & - & $10,000 \pm 3,000$ & $<\mathrm{DL}$ & $129,000 \pm 16,000$ & - & $340,000 \pm 60,000$ & - & $20,000 \pm 3,000$ & - \\
\hline B14 & - & - & $<\mathrm{DL}$ & $<\mathrm{DL}$ & - & $440,000 \pm 30,000$ & - & $11,400 \pm 700$ & - \\
\hline B15 & - & $30,000 \pm 4,000$ & $<\mathrm{DL}$ & $208,000 \pm 8,000$ & - & $14,200 \pm 500$ & - & $16,300 \pm 400$ & - \\
\hline B16 & - & $25,000 \pm 3,000$ & $<\mathrm{DL}$ & $52,900 \pm 1,400$ & - & $40,900 \pm 1,300$ & - & $13,200 \pm 1,100$ & - \\
\hline B17 & - & $8,200 \pm 1,000$ & $<\mathrm{DL}$ & $<$ DL & - & $330,000 \pm 6,000$ & - & $14,000 \pm 300$ & - \\
\hline B18 & - & $9,000 \pm 800$ & $<\mathrm{DL}$ & $42,500 \pm 700$ & - & $162,500 \pm 1,600$ & - & $6,800 \pm 140$ & - \\
\hline $\begin{array}{l}\text { Detection } \\
\text { Limit }\end{array}$ & & 5,500 & 3,000 & 1,500 & & & 500 & 200 & \\
\hline $\mathrm{C} 1$ & - & - & $5,200 \pm 400$ & $9,900 \pm 1,700$ & - & $1,800 \pm 200$ & $22,000 \pm 3,000$ & $13,400 \pm 1,800$ & - \\
\hline $\mathrm{C} 2$ & - & - & $4,200 \pm 500$ & $4,800 \pm 1,700$ & - & $1,400 \pm 200$ & $1,890 \pm 190$ & $2,500 \pm 300$ & - \\
\hline C3 & - & - & $<\mathrm{DL}$ & $<\mathrm{DL}$ & - & $800 \pm 60$ & $<$ DL & $2,590 \pm 110$ & - \\
\hline $\mathrm{C} 4$ & - & - & $<\mathrm{DL}$ & $10,000 \pm 2,000$ & - & $1,690 \pm 180$ & - & $1,910 \pm 100$ & - \\
\hline $\mathrm{C} 5$ & - & - & $<\mathrm{DL}$ & $7,600 \pm 300$ & - & $1,530 \pm 50$ & - & $1,480 \pm 60$ & - \\
\hline C6 & - & - & $<\mathrm{DL}$ & $12,000 \pm 3,000$ & - & $3,300 \pm 300$ & - & $2,040 \pm 180$ & - \\
\hline $\mathrm{C} 7$ & - & - & $3,800 \pm 500$ & $14,200 \pm 1,300$ & - & $2,600 \pm 200$ & - & $2,000 \pm 300$ & - \\
\hline $\mathrm{C} 8$ & - & - & $<\mathrm{DL}$ & $13,100 \pm 900$ & - & $76,000 \pm 5,000$ & - & $1,320 \pm 90$ & - \\
\hline $\begin{array}{l}\text { Detection } \\
\text { Limit }\end{array}$ & & 3,200 & & 2,200 & & 700 & 400 & 400 & \\
\hline D1 & $26,000 \pm 5,000$ & - & $<\mathrm{DL}$ & $7,300 \pm 700$ & - & $41,000 \pm 4,000$ & $34,000 \pm 3,000$ & $16,800 \pm 1,700$ & - \\
\hline D2 & - & - & $<\mathrm{DL}$ & $21,000 \pm 3,000$ & - & $31,100 \pm 1,700$ & - & $4,500 \pm 200$ & - \\
\hline D3 & - & - & $<\mathrm{DL}$ & $17,800 \pm 1,100$ & - & $6,430 \pm 130$ & - & $2,030 \pm 120$ & - \\
\hline D4 & - & - & $<\mathrm{DL}$ & $8,100 \pm 800$ & - & $2,550 \pm 80$ & - & $3,000 \pm 200$ & - \\
\hline D5 & - & - & $<\mathrm{DL}$ & $28,000 \pm 3,000$ & - & $2,600 \pm 200$ & - & $1,310 \pm 100$ & - \\
\hline D6 & - & - & $<\mathrm{DL}$ & - & - & $2,900 \pm 200$ & - & $7,200 \pm 600$ & - \\
\hline D7 & - & - & $<\mathrm{DL}$ & - & - & $10,510 \pm 190$ & $1,610 \pm 120$ & $2,200 \pm 130$ & - \\
\hline D8 & - & - & $<\mathrm{DL}$ & $2,900 \pm 600$ & - & $17,100 \pm 1,600$ & $<\mathrm{DL}$ & $2,400 \pm 300$ & - \\
\hline D9 & - & - & $<\mathrm{DL}$ & - & - & $5,100 \pm 300$ & - & $1,860 \pm 130$ & - \\
\hline D10 & - & - & $<\mathrm{DL}$ & - & - & $1,800 \pm 140$ & - & $900 \pm 80$ & - \\
\hline $\begin{array}{l}\text { Detection } \\
\text { Limit }\end{array}$ & 14,000 & & 3,600 & 2,400 & & 700 & 400 & 400 & \\
\hline
\end{tabular}

- element not detected

Source: The authors.

The divergence associated with the measurement of $\mathrm{K}$ is related to the overlap of spectral lines from different elements in the same region of $\mathrm{K}$ characteristic energy, which results in a less precise analysis of the element mentioned.

$\mathrm{Ca}$ was detected in four samples. In three samples (B9, C1 and C7), the results shown be statistically equal, only for the sample $\mathrm{C} 2$ the results disagreed.

Ti was detected in thirty-two samples. The t-test results showed that for eighteen samples - A1, A2, A4, B1, B2, B3, B4, B7, B9, B12, C1, C4, C6, C7, C8, D1 D4 and D5, the results proved to be statistically equivalent.

$\mathrm{Cr}$ was detected only in the sample $\mathrm{A} 1$, and $\mathrm{Cu}$ was detected in four samples (C1, C2, D1 and D7). The results obtained for these elements, when submitted to the t-test, shown be statistically equal.

Fe was detected in all analyzed samples. Af- 
Table 3 - Results of the elemental analysis of the eye shadows, obtained with the benchtop system.

\begin{tabular}{|c|c|c|c|c|c|c|c|c|c|}
\hline Sample & $\mathbf{C l}[\mu \mathrm{g} / \mathrm{g}]$ & $\mathbf{K}[\mu \mathbf{g} / \mathbf{g}]$ & $\mathrm{Ca}[\mu \mathrm{g} / \mathrm{g}]$ & $\mathbf{T i}[\mu \mathrm{g} / \mathbf{g}]$ & $\operatorname{Cr}[\mu \mathrm{g} / \mathrm{g}]$ & $\mathbf{F e}[\mu \mathrm{g} / \mathrm{g}]$ & $\mathbf{C u}[\mu \mathrm{g} / \mathrm{g}]$ & $\mathbf{Z n}[\mu \mathrm{g} / \mathrm{g}]$ & $\mathbf{B i}[\mu \mathrm{g} / \mathbf{g}]$ \\
\hline $\mathrm{A} 1$ & & & & $20,000 \pm 5,000$ & $42,000 \pm 6,000$ & $2,900 \pm 300$ & & $5,900 \pm 600$ & $20,000 \pm 3,000$ \\
\hline $\mathrm{A} 2$ & $*$ & & & $12,800 \pm 1,400$ & & $130,000 \pm 40,000$ & & $5,900 \pm 1,300$ & $29,000 \pm 7,000$ \\
\hline A3 & $*$ & $23,000 \pm 5,000$ & & & & $210,000 \pm 30,000$ & & $9,000 \pm 2,000$ & $36,000 \pm 8,000$ \\
\hline A4 & $*$ & $29,700 \pm 1,600$ & & $15,100 \pm 1,100$ & & $146,000 \pm 18,000$ & & $17,700 \pm 1,900$ & $67,000 \pm 3,000$ \\
\hline B1 & & $29,000 \pm 3,000$ & & $59,000 \pm 6,000$ & & $12,500 \pm 1,100$ & & $8,300 \pm 500$ & \\
\hline B2 & & & & $76,000 \pm 10,000$ & & $8,000 \pm 400$ & & $6,300 \pm 200$ & \\
\hline B3 & & $16,000 \pm 4,000$ & & $100,000 \pm 30,000$ & & $7,200 \pm 1,300$ & & $11,100 \pm 1,700$ & \\
\hline B4 & & $13,200 \pm 800$ & & $53,000 \pm 4,000$ & & $2,760 \pm 170$ & & $8,200 \pm 800$ & \\
\hline B5 & & $24,900 \pm 1,600$ & & $58,000 \pm 4,000$ & & $29,000 \pm 2,000$ & & $11,000 \pm 1,000$ & \\
\hline B6 & & $23,000 \pm 4,000$ & & $142,000 \pm 18,000$ & & $730,000 \pm 50,000$ & & $16,200 \pm 1,300$ & \\
\hline B7 & & $11,800 \pm 1,200$ & & $65,000 \pm 7,000$ & & $4,000 \pm 400$ & & $6,000 \pm 500$ & \\
\hline B8 & & & & $30,000 \pm 2,000$ & & $1,950 \pm 150$ & & $7,400 \pm 1,300$ & \\
\hline B9 & & & $2,600 \pm 400$ & $39,000 \pm 6,000$ & & $2,600 \pm 400$ & & $14,400 \pm 1,600$ & \\
\hline B10 & & & & $2,100 \pm 300$ & & $220,000 \pm 30,000$ & & $7,600 \pm 800$ & \\
\hline B11 & & $14,000 \pm 1,000$ & & $43,000 \pm 2,000$ & & $15,000 \pm 1,200$ & & $6,900 \pm 400$ & \\
\hline B12 & & & & $34,000 \pm 4,000$ & & $1,700 \pm 300$ & & $5,000 \pm 1,000$ & \\
\hline B13 & & $12,000 \pm 2,000$ & & $100,000 \pm 20,000$ & & $250,000 \pm 50,000$ & & $12,000 \pm 3,000$ & \\
\hline B14 & & & & & & $600,000 \pm 200,000$ & & $14,000 \pm 5,000$ & \\
\hline B15 & & $36,000 \pm 10,000$ & & $180,000 \pm 40,000$ & & $14,000 \pm 3,000$ & & $13,000 \pm 2,000$ & \\
\hline B16 & & $27,000 \pm 2,000$ & & $48,000 \pm 3,000$ & & $40,000 \pm 4,000$ & & $12,000 \pm 3,000$ & \\
\hline B17 & & $13,000 \pm 2,000$ & & & & $390,000 \pm 40,000$ & & $15,300 \pm 1,700$ & \\
\hline B18 & & $10,830 \pm 140$ & & $39,900 \pm 800$ & & $175,000 \pm 3,000$ & & $6,390 \pm 130$ & \\
\hline $\mathrm{C} 1$ & & & $4,800 \pm 1,800$ & $11,000 \pm 5,000$ & & $2,500 \pm 1,100$ & $25,000 \pm 11,000$ & $15,000 \pm 7,000$ & \\
\hline $\mathrm{C} 2$ & & & $2,100 \pm 800$ & $2,000 \pm 2,000$ & & $1,300 \pm 400$ & $1,600 \pm 400$ & $1,800 \pm 500$ & \\
\hline $\mathrm{C} 3$ & & & & & & $1,100 \pm 100$ & & $2,070 \pm 180$ & \\
\hline $\mathrm{C} 4$ & & & & $8,000 \pm 6,000$ & & $1,700 \pm 400$ & & $1,400 \pm 200$ & \\
\hline $\mathrm{C} 5$ & & & & $6,600 \pm 800$ & & $1,510 \pm 160$ & & $1,250 \pm 130$ & \\
\hline C6 & & & & $9,000 \pm 6,000$ & & $2,800 \pm 700$ & & $1,400 \pm 400$ & \\
\hline $\mathrm{C} 7$ & & & $3,700 \pm 900$ & $13,600 \pm 1,100$ & & $2,900 \pm 300$ & & $2,100 \pm 1,200$ & \\
\hline $\mathrm{C} 8$ & & & & $13,000 \pm 700$ & & $73,000 \pm 12,000$ & & $1,050 \pm 190$ & \\
\hline D1 & & & & $8,000 \pm 4,000$ & & $49,000 \pm 19,000$ & $37,000 \pm 16,000$ & $17,000 \pm 7,000$ & \\
\hline D2 & & & & $16,000 \pm 5,000$ & & $31,400 \pm 1,300$ & & $4,200 \pm 600$ & \\
\hline D3 & & & & $10,700 \pm 1,300$ & & $5,050 \pm 70$ & & $1,430 \pm 130$ & \\
\hline D4 & & & & $8,500 \pm 600$ & & $2,870 \pm 70$ & & $3,000 \pm 900$ & \\
\hline D5 & & & & $26,000 \pm 2,000$ & & $2,600 \pm 200$ & & $1,100 \pm 300$ & \\
\hline D6 & & & & & & $3,200 \pm 1,200$ & & $7,000 \pm 3,000$ & \\
\hline D7 & & & & & & $11,000 \pm 3,000$ & $1,700 \pm 400$ & $1,900 \pm 700$ & \\
\hline D8 & & & & $4,300 \pm 1,100$ & & $25,000 \pm 8,000$ & & $2,900 \pm 1,100$ & \\
\hline D9 & & & & & & $4,700 \pm 900$ & & $1,500 \pm 300$ & \\
\hline D10 & & & & & & $1,800 \pm 400$ & & $700 \pm 200$ & \\
\hline
\end{tabular}

*element not detected due to the overlapping of the $\mathrm{Cl}$ peaks with the peaks from the Xray tube Source: The authors.

ter the t-test application, it was possible to verify that $\mathrm{Fe}$ results were statistically equal for 21 samples - A4, B2, B3, B5, B8, B10, B15, B16, C2, C4, C5, C6, C7, C8, D1, D2, D5, D6, D7, D9 and D10.

$\mathrm{Zn}$ is another element detected in all the samples. The results were statistically equivalent only for twelve samples - B10, B14, B16, C1, C7, D1, D2, D4, D5, D6, D7 and D8, according to the t-test.
$\mathrm{Bi}$ was detected in the four samples from manufacturer $\mathrm{A}$ and the results for the samples A1 and A3 proved to be statistically equal after the t-test application.

It is important to emphasize that despite the same technique was used in the results comparison, the quantification procedure was different. While a calibration curve, obtained from mono-element standards from Micromatter ${ }^{\mathrm{TM}}$, was used for the portable system results, in the bench top equipment the quantification was performed based in the fundamental parameters, using the spectrometer software. 


\section{Principal Component Analysis}

Figure 2 shows an overlap of the EDXRF spectra obtained for the 40 eye shadow samples. Each spectrum refers to the average spectrum of 12 measurements.

Figure 2 - Overlap of the EDXRF spectra from the samples analyzed.

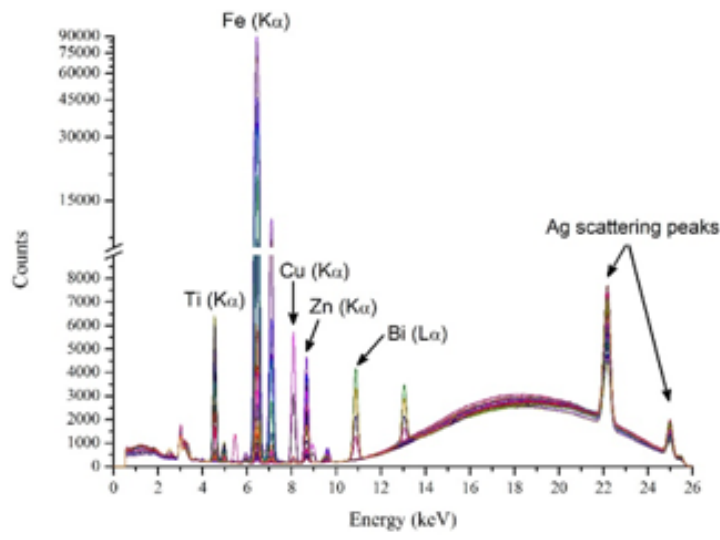

Source: The authors

Relying on its multi-dimensional feature, the set of X-ray spectra was evaluated by PCA. The data were mean-centred before the analysis and leaveone-out cross-validation was applied. The entire Xray spectrum has been considered in the analysis. Figure $3 \mathrm{a}$ shows the scores plot of PC1xPC2 and it is possible to verify a separation of the samples. The loadings plot, Figure $3 \mathrm{~b}$, shows the relevant variables that provided this separation.

The greater separation is due to the Fe content in each sample and is related to its colors and hues. The samples that stand out in the scores plot exhibit dark colors and hues. It is also possible to verify that the set of samples " $\mathrm{B}$ " is separated from the others due to $\mathrm{Ti}$, whereas the sets of samples "A", "C" and "D" are grouped due to X-ray elastic scattering intensity, expressed in the Ag peaks.

Since the PC corresponding to the Fe content in the cosmetic samples can explain $97.95 \%$ of the data variance the same set of EDXRF spectra was evaluated by PCA once again, this time excluding the variables corresponding to $\mathrm{Fe}-\mathrm{K} \alpha(\approx 6.40 \mathrm{keV})$ and $\mathrm{Fe}-\mathrm{K} \beta(\approx 7.06$ $\mathrm{keV})$ peaks.

Figure 4a shows the scores plot of PC1xPC 3. Together, these PCs account for over $65 \%$ of the variance contained in the data. A separation of the samples into groups is
Figure 3 - The (a) scores plot and the (b) loadings plot associated with $\mathrm{PC} 1$ and $\mathrm{PC} 2$ from principal components analysis of the set of EDXRF spectra set.

(a)

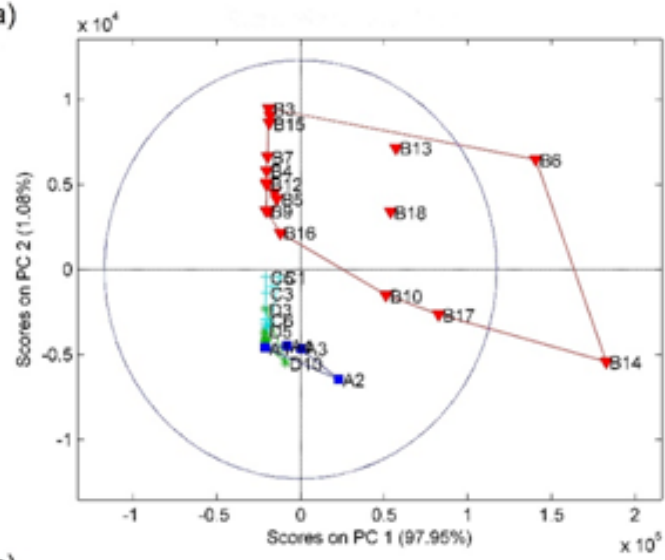

(b)

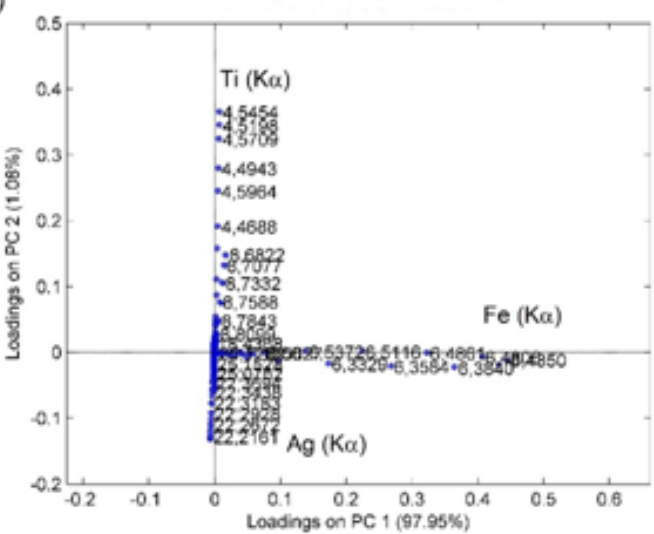

Source: The authors.

verified according to the manufacturer. The loadings plot (Figure 4b) shows the relevant variables that provided this separation, i.e., Ti, Zn, Bi and Ag scattering peaks.

Confronting the scores and the loadings plot, it is notable that $\mathrm{Ti}$ and $\mathrm{Zn}$, and the probable presence of titanium dioxide and zinc stearate, are crucial when discriminating samples from manufacturer "B". The presence of $\mathrm{Bi}$, associated with the additive bismuth oxychloride, is the decisive factor in the separation manufacturer "A" samples. The X-ray elastic scattering peak intensity is responsible for the manufacturers " $\mathrm{C}$ " and "D" samples separation, indicating that these samples have higher levels of organic compounds compared to the samples from the other brands. This procedure has direct applications in forensic science for brand identification, where the identification of a particular material can be essential to elucidate the sequence of events in a crime scene or to establish the relationship among subjects and facts. 
Figure 4 - The (a) scores plot and the (b) loadings plot associated with PC1 and PC3 from principal components analysis of the set of EDXRF spectra, excluding the variables corresponding to $\mathrm{Fe}-\mathrm{K} \alpha$ and $\mathrm{Fe}-\mathrm{K} \beta$ peaks.
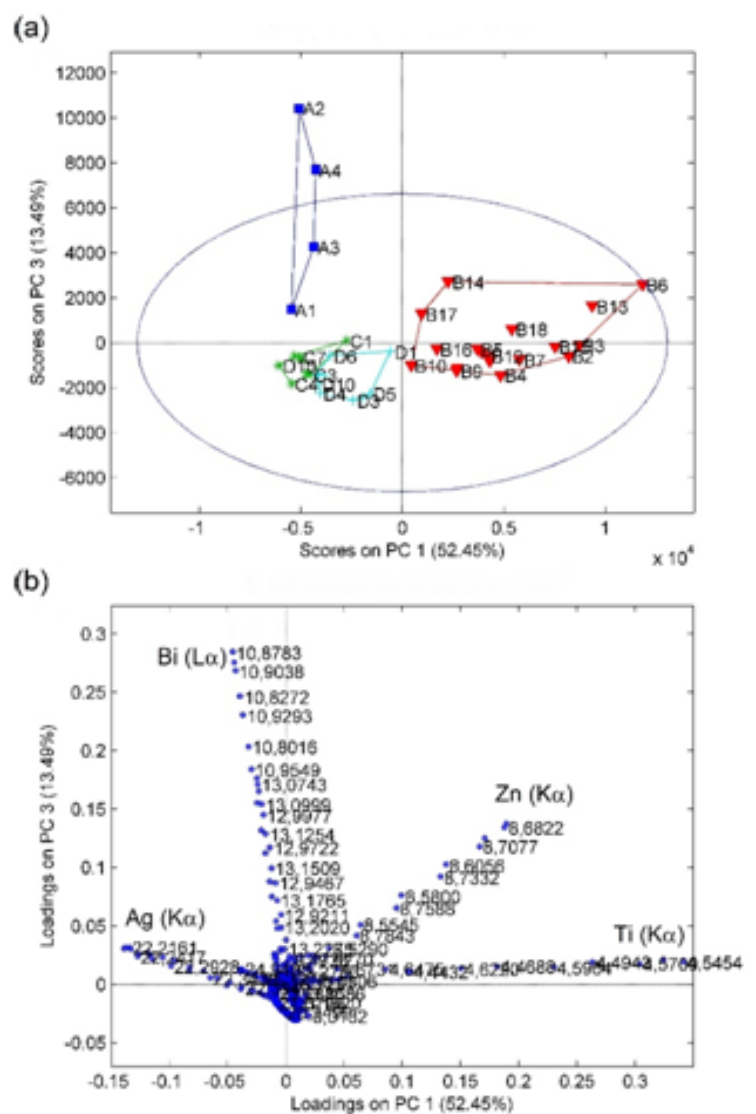

Source: The authors.

\section{Conclusions}

With the methodology presented in this study the total content of various inorganic elements were determined in the samples, either as carrier material or as pigments in the manufacture process of eye shadows. Also, the provenance of the cosmetics related to its manufacturer was differentiated.

Portable EDXRF systems present a high-speed analytical technique with minimum sample preparation as well as the possibility of in situ analysis. The X-ray fluorescence methodology associated with principal component analysis presents as a valuable tool for the differentiation and characterization of cosmetics samples. This methodology can be improved in order to be employed in the forensic area as well as in the quality assurance of industries and by the governmental agencies of inspection.

\section{Acknowledgments}

The authors are thankfully for the financial support by CNPq (483840/2013-0) and to the CAPES by the scholarship for the first author. This work is part of the project INCT-FNA Proc. No. 464898/2014-5.

\section{References}

BAREL, A. O.; PAYE, M.; MAIBACH, H. Cosmetic science and technology. New York: John Willy and Son Inc. Hal, 2009. p. 626-629.

BATISTA, E. F; SANTOS, A. A.; PEREIRA-FILHO, E. R. Determination of $\mathrm{Cd}, \mathrm{Co}, \mathrm{Cr}, \mathrm{Cu}, \mathrm{Ni}$ and $\mathrm{Pb}$ in cosmetic samples using a simple method for sample preparation. Analytical Methods, New York, v. 7, n. 1, p. 329-335, 2015. Doi: <https://doi.org/10.1039/C4AY02484B>

BRIGGS-KAMARA, M. A. Elemental analysis of selected epidermal creams by X-ray Fluorescence (XRF) Spectrometry. International Journal of Emerging Technology and Advanced Engineering, Madhya Pradesh, v. 2, n. 5, p. 334-340, 2012.

CURRIE, L. A. Limits for qualitative detection and quantitative determination: application to radiochemistry. Analytical chemistry, Washington, v. 40, n. 3, p. 586-593, 1968. Doi: <http://doi.org/10.1021/ac60259a007>

DASILVA, E.; DAVID, A. M.; PEJOVIĆ-MILIĆ, A. The quantification of total lead in lipstick specimens by total reflection X-ray fluorescence spectrometry. X-Ray Spectrometry, London, v. 44, n. 6, p. 451-457, 2015. Doi: <http://dx.doi.org/10.1002/xrs.2629>

DRAELOS, Z. D. Special considerations in eye cosmetics. Clinics in dermatology, [S.1.], v. 19, n. 4, p. 424-430, 2001. Doi: <http://dx.doi.org/10.1016/S0738-081X(01) 00204-8>

GONDAL, M. A.; SEDDIGI, Z. S.; NASR, M. M.; GONDAL, B. Spectroscopic detection of health hazardous contaminants in lipstick using laser induced breakdown spectroscopy. Journal of Hazardous Materials, Amsterdam, v. 175, n. 1/3, p. 726-732, 2010. Doi: <https://doi.org/10.1016/j.jhazmat.2009.10.069> 
KULIKOV, E.; LATHAM, K.; ADAMS, M. J. Classification and discrimination of some cosmetic face powders using XRF spectrometry with chemometric data analysis. X-Ray Spectrometry, London, v. 41, n. 6, p. 410-415, 2012. Doi: <http://dx.doi.org/10.1002/xrs.2422>

MCINTOSH, K. G. et al. Evaluation of portable XRF instrumentation for assessing potential environmental exposure to toxic elements. International Journal of Environmental Analytical Chemistry, New York, v. 96, n. 1, p. 15-37, 2016. Doi: <https://doi.org/10.1080/03067319. 2015.1114104>

MELQUIADES, F. L.; PARREIRA, P. S.; ENDO, L. Y.; SANTOS, G.; WOUK, L.; PORTEZAN FILHO, O. Portable EDXRF for quality assurance of cosmetics. Cosmetics, Oak Park, v. 2, n. 3, p. 277-285, 2015. Doi: <http://dx.doi.org/10.3390/cosmetics2030277>

MELQUIADES, F. L.; SILVA, A. M. A. Identification of sulphur in nail polish by pattern recognition methods combined with portable energy dispersive X-ray fluorescence spectral data. Analytical Methods, New York, v. 8, n. 19, p. 3920-3926, 2016. Doi: <http://doi.org/10.1039/ C6AY00195E>

MISRA, G.; SAWHNEY, K. J. S.; LODHA, G. S.; MITTAL, V. K.; SAHOTA, H. S. The application of energydispersive $\mathrm{x}$-ray fluorescence spectrometry (EDXRF) to the analysis of cosmetic evidence in Indian nail polishes. International journal of radiation applications and instrumentation. Part A. Applied radiation and isotopes, New York, v. 43, n. 5, p. 609-614, 1992. Doi: <http://doi.org/10.1016/0883-2889(92)90028-D>

MURPHY, Thomas et al. Application of handheld xray fluorescence analyzers to identify mercury in skinwhitening creams in cambodia. Journal of Health and Pollution, New York, v. 2, n. 3, p. 21-31, 2012. Doi: <http: //dx.doi.org/10.5696/2156-9614-2.3.21>

PARISH, L. C.; CRISSEY, J. T. Cosmetics: a historical review. Clinics in dermatology, [S.1.], v. 6, n. 3, p. 1-4, 1988. Doi: <http://doi.org/10.1016/0738-081X(88)90024-7>
PARREIRA, Paulo Sérgio et al. Sistema portátil de fluorescência de raios $X$. Londrina: Universidade Estadual de Londrina, 2019. BR n. PI 0801331-4. Depósito: 5 maio 2008. Concessão: 12 mar. 2019.

SANTOS, A. A.; BATISTA, E. F.; PEREIRA-FILHO, E. R. Direct chemical inspection of eye shadow and lipstick solid samples using laser-induced breakdown spectroscopy (LIBS) and chemometrics: proposition of classification models. Analytical Methods, New York, v. 8, n. 29, p. 5851-5860, 2016. Doi: <https://doi.org/10.1039/ C6AY01138A>

SANTOS, B. V.; OLIVEIRA JÚNIOR, J. M.; BONVENTI JÚNIOR, W.; HANAI-YOSHIDA, V. M. Assessment of chemical elements in cosmetics' eyeshadows by X-ray fluorescence and International Nomenclature of Cosmetic Ingredients characterization. X-Ray Spectrometry, London, v. 47, n. 3, p. 242-251, 2018. Doi: $<$ https://doi.org/10.1002/xrs.2835>

SHIMAMOTO, G. G.; TERRA, J.; BUENO, M. I. Use of portable X-ray fluorescence to discriminate brands of nail polishes: a potential forensic tool. Journal of the Brazilian Chemical Society, São Paulo, v. 24, n. 5, p. 731-735, 2013. Doi: <http://dx.doi.org/10.5935/0103-5053.20130093>

VAN GRIEKEN, R.; MARKOWICZ, A. (ed.). Handbook of $X$-ray Spectrometry. Boca Raton: CRC press, 2001.

WESTMORE, M. G. Camouflage and makeup preparations. Clinics in dermatology, [S.1.], v. 19, n. 4, p. 406-412, 2001. Doi: <http://dx.doi.org/10.1016/S0738-081X(01) 00180-8>

WOLD, S.; ESBENSEN, K.; GELADI, P. Principal component analysis. Chemometrics and intelligent laboratory systems, Amsterdam, v. 2, n. 1/3, p. 37-52, 1987. Doi: <http://doi.org/10.1016/0169-7439(87)80084-9> 
